\title{
ICT deployment and resource-based power in multinational enterprise futures
}

\author{
Mo Yamin ${ }^{1}$, Rudolf R. Sinkovics* \\ The University of Manchester, Manchester Business School, Booth Street West, Manchester M15 6PB, United Kingdom
}

\section{A R T I C L E I N F O}

\section{Article history:}

Available online 18 August 2010

\section{Keywords:}

Enterprise resource planning (ERP)

Resource dependency

Power

Embeddedness

Legitimacy

Visibility

\begin{abstract}
A B S T R A C T
Applying a resource-dependency perspective to intra-multinational enterprise (MNE) power [55,56], this paper examines the effect of the deployment of advanced ICT and particularly the implementation of enterprise resource planning (ERP) systems. Although subsidiaries in the multinational do not have authority-based or 'structural' power with respect to key strategic decisions [6,16], they may have 'resource-based' power in the form of knowledge and capabilities that is of value to the multinational as a whole. Business network analysis highlights the 'invisibility' of the external networks (often in the host country) to the upper echelons in the multinational through which valuable subsidiary knowledge and capabilities develop. It points out that this 'invisibility' undermines the headquarters' ability to control the subsidiary $[3,28,36,44,70,74]$. In this paper we argue that the deployment of ERP undermines the resource base of subsidiary power and thus helps to restore greater central authority in the MNE. The paper reports findings from studies in twelve MNEs which have implemented ERP and points out that from the perspective of subsidiary managers a key effect of ERP deployment is the reduction in their autonomy. This may have significant adverse implications for the futures of the MNE as a federative organizational form and the legitimacy of MNE operations abroad.
\end{abstract}

Crown Copyright (c) 2010 Published by Elsevier Ltd. All rights reserved.

\section{Introduction and motivation}

As an organization, the multinational enterprise (MNE) has an inherent tendency towards a federative structure [31] in which subunits develop an autonomous knowledge base and thus a degree of strategic independence from the centre. In particular, subsidiaries develop 'embedded' relationships in (mostly local) business networks which significantly enhance their ability for strategic actions [29]. However this creates a tension between the MNE as a managerial hierarchy and the MNE as an organizational structure. Arguably, the federative structure of the MNE has been unfavorable to managers, especially those in the top echelon of multinational headquarters. Their response will thus be to limit the federative character of multinationality in various ways. Whilst management scholars have implicitly recognized that the MNE's federative nature is inimical to the MNE's controlling elites they have overestimated the effectiveness of the softer, value or 'culture' based methods in overcoming the hurdles that the federative structure creates for control [29,66]. Furthermore due to broader socio-political changes, notably the shift in the governance regime towards shareholder value, the intolerance

\footnotetext{
* Corresponding author. Tel.: +44 1613068980.

E-mail addresses: Mo.Yamin@manchester.ac.uk (M. Yamin), Rudolf.Sinkovics@manchester.ac.uk (R.R. Sinkovics).

URL: http://www.personal.mbs.ac.uk/myamin/, http://www.personal.mbs.ac.uk/rsinkovics/

1 Tel.: +441613063462.
} 
towards the federative tendencies in the MNE has probably been increasing. At the same time information and communication technology (ICT) advances may have boosted the control capability of the headquarters. Thus ICT enables greater effectiveness and transparency in the information flow from subsidiaries and reduces the 'invisibility' of subsidiary networks in the host economy which is often seen as the main driver of subsidiary autonomy in the federative structure. However, whilst the application of ICT may enable the MNE headquarter to establish control, this may not necessarily serve the long-term viability of the MNE. As Levinthal and March [45] observe, 'organizational power is a short-term asset but potentially a long-term liability' ([45], p.102). Thus, in our context, ICT application enhances the power of the centre to impose a standardized streamlined organizational structure, which constrains subsidiaries in their institutional agenda and forces them to adhere tightly to central directives. It further undermines the scope for social entrepreneurship or local networking. A number of scholars have recently noted this as being central to the future viability of MNE strategies, particularly in emerging economies, arguably the most dynamic components of the world economy [46].In this paper we investigate the impact of ICT application through the resourcedependency perspective which provides a useful framework for exploring the intra-MNE tussle for power as both the power of the HQ and the subsidiary have significant resource underpinnings. We investigate the possible impact of the application of ICT on MNE structure from a resource-dependency perspective and then comment on possible implications for future MNE viability with respect to emerging responsiveness challenges. We look at this particularly in the context of emerging economies.

\section{A conceptual perspective on the relationship between MNE headquarters and foreign subsidiaries}

The international business literature suggests a theoretical framework which sees the structure of decision making in multinational enterprises as being partly dependent on how competing pressures for global integration and national responsiveness impinge on the multinational. For a subsidiary, host country responsiveness is particularly conducive to its gaining knowledge-based resources, largely independent of the rest of the MNE. More precisely, a subsidiary's autonomy and its ability to influence decision making processes within the MNE is largely shaped by the degree to which the subsidiary has gained knowledge and skills through its interaction with counterparts in the host environment.

Literature focusing on subsidiary role typologies and subsidiary initiatives has highlighted the importance of local market responsiveness in shaping subsidiary role developments $[8,11,14,38,59,68]$. Other studies have highlighted subsidiary local 'embeddedness' as an important factor in its capability development including its innovation (or 'knowledge building') and knowledge transfer activities [4,5,29].

The resource-dependency perspective [19,55,56] has been applied by several authors to analyze the implications of subsidiary knowledge for its power in the multinational structure [4,5,23,29,31,48]. Thus, although subsidiaries do not have authority-based power with respect to key strategic decisions $[6,16,69]$, they may have 'resource-based power' in the form of knowledge and capabilities to the extent that this knowledge or capability is of value to the multinational as a whole. A subsidiary's knowledge-based resources can endow it with 'negative' power; basically, the power to assert autonomy and avoid control from the centre $[3,27,73]$. Such resources can also be a source of the subsidiary's 'positive' power - that is, an ability to exert 'influence' defined as 'informal attempts to affect issues and behavior indirectly' over strategic issues ([5], p. 321). A number of empirical studies have highlighted the 'positive' power of subsidiaries rooted in their knowledge-based resources. Mudambi and Navarro [52] analyze subsidiary power based on locally generated knowledge, in terms of the subsidiary's ability to negotiate a favorable distribution of organizational rents whilst other studies specifically focus on the ability to influence the multinational's strategy $[4,5,29]$. The study by Femer et al. [26] points to a similar conclusion in the context of HRM policies.

Studies indicate that federative MNEs cannot rely exclusively on formal control mechanism such as centralization and formalization. It is imperative for them to directly engage with subsidiaries [35] in terms of assigning, negotiating (and at times suppressing) subsidiary roles and initiatives [8,11,13,14]. Managing the organizational tussle with powerful subsidiaries $[4,28,52]$ involves cajoling or 'persuading' subsidiaries to trade-off their autonomy or 'negative' power for greater, multinational-wide, responsibilities or mandates [30].

\subsection{Governance regimes, financialization and the reduced tolerance for federative structures}

Business network analysis highlights the 'invisibility' to the upper echelons in the multinational of the external networks (often in the host country) through which valuable subsidiary knowledge and capabilities develop and points out that this 'invisibility' undermines the headquarters' ability to control the subsidiary [3,28,37,43]. The invisibility of the subsidiary's network is the inevitable consequence of embeddedness and is due to the opaqueness of network relationships and interdependencies to outsiders. This is not simply an agency problem whereby the local mangers may deliberately hide relevant information from their principals further up the MNE hierarchy, although this may also happen. MNE's upper echelon tends to have at best a fuzzy and rather vague understanding of the subsidiary's network and this undermines their ability to control the subsidiary. Thus, the most critical consequence of subsidiary embeddedness is that it creates a 'knowledge deficit' for the centre with regards to the subsidiary's operating environment and hence its resource and power base. Also, because the required knowledge relates primarily to subsidiary network context and would lack transparency to outsiders, the efficacy of the MNE's formal communication system is limited. 
However, arguably, subsidiary business networks could only flourish because the dominant governance model (pertaining to the large oligopolistic enterprises) in much of the post war period entailed a recognition of the necessity of long-term commitment to innovation and thus was sympathetic to the development of long-term business relationships. O'Sullivan [54] argues that this has been critical to the functioning of the successful Chandlerian firm, helping to foster process and product innovation over the long term. The governance regime implied 'insider control' (i.e. putting strategic control within corporations in the hands of those who as insiders have the incentive and the abilities to allocate resources to innovative investment). In the Chandlerian perspective, control and governance of the firm is essentially a managerial process, the involvement of outsiders notably from the ownership/ finance arena is 'hands-off' and permissive with respect to managerial autonomy. Most large companies relied on retained earnings rather than the stock market as a source of investment finance. Thus financial markets 'left management alone to use cash flow to finance such capital accumulation and innovation as changes in the product markets, pressures and opportunities indicated was best for the long-term growth of the firm' [21, p. 88]. We may surmise that such 'stakeholders' would not particularly have concerned themselves with the control ramifications of a subsidiary's external networks. Put simply, with the progress of globalization and financialization, the broad environment of international business is no longer conducive or helpful vis-à-vis subsidiary embeddedness. In particular the change in the governance regime, away from the 'retain and reinvest' imperative towards shareholder value maximization has led to the ascendancy of financial agents, notably institutional investors and the increasing alignment of top management and shareholder interests through the rapidly increasing significance of share-options in top management remuneration. Consequently there is much greater pressure on companies to 'disgorge' earnings to financial markets [21].

We suggest that this shift in the governance regime has dramatically reduced the tolerance of MNE HQs, particularly the corporate HQs, with respect to subsidiary power and has increased the pressure for structural change. The ascendancy of and increasing pressures from financial market have resulted in a shift from an 'organizational integration' to a 'financial' or 'portfolio' conception of the large, multiunit firm [21]. Corporate HQs transmit pressures further down the hierarchy, partly through enforcing more 'focused' structures with increasing central control [51].

\subsection{ICT and the changing structure of power in $H Q$-subsidiary relationships}

Whilst developments on the governance front have significantly increased the incentives for corporate HQs to exert control, other developments may have enhanced the control capability of the HQs [74]. In particular the deployment of ICT can potentially destroy the invisible structures around embedded subsidiaries. By enabling or at least facilitating structural change which is more conducive to central control, this can also be explained using Foucault's panopticon metaphor in connection with information systems [63]. ICT has 'enabling power' [7] for MNE headquarters, it allows these to put subsidiary networks under surveillance, a state of conscious and permanent visibility, that strengthens central control and enacts power. Thus propelled by pressures emanating from financial markets, and enabled by radical advances in ICT, MNE headquarters have sought either to destroy subsidiary networks and/or to 'penetrate' them, overcoming their knowledge deficit. Yamin and Forsgren [73] explain the preponderance of regional MNEs in terms of the centre's need for proximity to its important subsidiaries and as a manifestation of the network penetration tactic. Here, we focus on structural changes that have effectively destroyed subsidiary networks. The demise of the federative MNE is associated with two developments, the drastic reduction in subsidiary value chain scope and increasing offshoring and outsourcing of core activities. We posit that both developments are facilitated by substantial technological advancements, particularly ICT-integration and ICTadvancement activities [39-42] in the form of ERP.

Buckley and Ghauri [17] point out that MNE strategies now revolve around the disintegration of the value chain: 'The managers of MNEs are increasingly able to segment their activities and to seek the optimal location for increasingly specialized slivers of activity' [17, p. 83, emphasis added]. The disintegration of subsidiary value adding activities clearly undermines the scope for the development of external linkages by the subsidiary. The important point is that even if a particular host country is chosen as an optimal location for several value adding activities they are not integrated 'horizontally' within the same country but vertically within a global business unit usually managed from outside of the host country. Thus, in sharp contrast to the typical federative structures, subsidiaries are increasingly 'networked' internally within the MNE of which they are part and decreasingly 'networked' with the national economies in which they are located $[10,72]$.

The disintegration of host country based value chains is itself a function of two inter-related developments, namely the growth of 'global' customers ('global accounts' or clients) [12,62] and increasing ability at the centre to deploy ICT based support systems to achieve global integration of the supply chain at the corporate or divisional (as opposed to national subsidiary) level. The production system is increasingly modularized, facilitated through a machine based and highly codified knowledge system. Coordination no longer requires communication of highly tacit knowledge and essentially enhances the 'visibility' of subsidiary operations through electronic integration [33]. ICT has a facilitating role in the information exchange between headquarters and subsidiaries. The electronic integration, i.e. linking of headquarters, subsidiaries and other external networks of suppliers brings out an increased visibility of subsidiary behavior and achievements.

A parallel development is the growth of outsourcing. The relevance of outsourcing in terms of the demise of the federative MNE is that, through outsourcing, the MNE centre shifts from invisible networks around subsidiaries to visible networks controlled by the centre itself. Nolan et al. [53] document the extension of coordination and planning by 'systems integrator' 
firms with 'aligned' upstream 'first tier suppliers' regarding production location, R\&D, product development, and with 'downstream' distribution and maintenance. Thus, externalization actually helps shift the balance of power in favor of control and planning by the MNE centre $[53,67]$.

Thus developments in ICT impacted the structure of the relations between HQs and subsidiary in two related ways. First by helping in the process of modularization and value chain disintegration it has reduced the resource base for subsidiary power as the reduction in the subsidiary's value chain scope in turn reduces its ability to develop local linkages or gain important tacit knowledge rooted in such. Second, since the 1980 s globalization drivers have dramatically intensified both the desire and the ability to control operations from the centre of the MNE. A key facilitator has been the application of various ICT mechanisms to significantly upgrade the monitoring capability at the centre and thus to engender much greater 'visibility' in the vertical information system of the organization. From a resource-dependency perspective this development seriously undermines power of subsidiaries to exert influence over strategic issues (such as investment allocations to their local markets) as the key resource of subsidiaries is likely to be rooted in their linkages and business networks in host countries. In the remainder of this paper we focus on the latter effect by examining the implication of the adoption of ERP system for subsidiary autonomy.

\section{Methodology}

The conceptual thinking of the previous section motivated our further empirical steps. The nature of our investigation in this study is exploratory, thus we sought interview support from multinational enterprises which had recently (i.e. within the last 3 years) installed or upgraded to an ERP system such as, e.g. SAP, Oracle, IBM or Exactsoftware. The aim was to augment our understanding of the role of ICT in the governance of the relationship between HQ and subsidiaries and to gauge subsidiary managers' perspectives of the changes which resulted from the introduction of ERP systems. In our procedure we were inspired by Easterby-Smith et al. [24] who argue that a qualitative approach can grant for flexibility that allows for fluid and continual renegotiation of central dimensions and thus pursued a qualitative procedure facilitated by semi-structured interview [65].

\subsection{Participants and procedure}

Target respondents were IT-managers or general management staff of subsidiaries who had active involvement in the managerial process of selecting and implementing the ERP system. In obtaining access to relevant individuals, we proceeded on theoretical grounds rather than sampling from a large-scale database [20] and gradually developed networks and asked for cooperation from industry leaders in the United Kingdom. To secure industry participation and cooperation, we drew on elements of the Dillon's 'Tailored Design Method' [22] which, although primarily geared up for survey research, proved very useful in our context. Before meeting for the interviews, we had established multiple contacts via phone, provided detail information about the project and our expectations regarding the interviews, and were thus confident in meeting requirements regarding 'social exchange' [22,25], which supported the quality of the interviews and responses.

\subsection{Interview material}

Respondents were asked to reflect on real-life events surrounding the selection and implementation of the ERP system in their company, the process was guided by thinking of the critical incident technique [32]. Specifically, interviewees were asked to reflect on the biggest benefits and/or positive consequences of the ERP system implementation in HQ-subsidiary interaction and the biggest drawbacks and/or negative consequences of this process. Further open questions were put forward, such as how the use of ERP changed the formal structure of the HQ-subsidiary relationships, how it changed the informal structure and whether the ERP system rendered the subsidiaries more or less significant in terms of intraorganizational negotiations and decision making. Furthermore, some closed-end questions were included in the interview guideline for classification purposes and to obtain sound assessment on respondents' opinions.

We were successful in obtaining a total number of 15 interviews from managers who had been directly involved or overseen the ERP deployment as members of a project team in a total of 12 MNEs. This ERP system installation which managers were familiar with, was introduced during the past 5 years and managers were supposed to be familiar with and remember key events. The interviews were transcribed and categorized subsequently following formalized procedures recommended in the qualitative methodology literature [64,65].

\section{Results}

\subsection{Decision making}

We see from Table 1 that while decision making regarding business decisions is often shared with subsidiaries, IT decisions and most importantly ERP decisions are mostly determined at the HQ level. This also explains why most of the ERP solutions in the range of companies we interviewed were mostly fully integrated ERP solutions (10 responses), which cover the whole range of business activities between HQ and subsidiaries and did not leave room for subsidiary specific installations or alterations. 
Table 1

Decision making - HQ versus subsidiary.

\begin{tabular}{llll}
\hline & HQ all of the time & HQ very often & HQ often \\
\hline Business decisions (HRM, bus solutions, marketing) & 6 & 3 & 3 \\
IT decisions & 4 & 5 & 4 \\
ERP decisions & 9 & 5 & 2 \\
\hline
\end{tabular}

The argument provided to us, when asked which factor influenced most strongly the choice between centralized or fragmented ERP solutions, managers pointed us towards "better control and access to information" (14 responses) as well as "greater visibility of operational decision making” (15 responses). This clearly highlights the fact that, when provided with the opportunity, HQ-managers are delighted to reduce the strategic information deficit which exists between the centre and the subsidiaries. ERP systems apparently provide an opportunity for the HQ to exert higher levels of control over subsidiaries, not only residing on the traditional strategic level and limiting themselves to output control [2,18], but also moving towards higher levels of operational control and influencing the visible consequences and performance of a partner's actions such as delivery time, order accuracy and product quality [34,60].

The following responses which emanated from managers, when asked about the biggest benefits/advantages of adopting ERP systems, are indicative of the positions provided:

- "Better visibility of organizational impact and performance. Along with the ability to change factors, that may affect the performance of the company positively"

- "...integrated database where all information is available in one place... This centralizes management and planning processes"

- "in our company integration for control and direction of subsidiaries with headquarters is primarily done through ERP solutions. ...control of subsidiaries by headquarter has improved and is more precise"

It is clear from these comments that visibility of subsidiaries from the headquarters' perspective and the potential for control has improved due to ERP implementation. Interestingly, and in contrast to expectations, subsidiary managers do not necessarily view this development towards more centralized management and/or planning processes negatively. Positive perspectives which are commonly suggested from the perspective of headquarter management, are shared by subsidiary managers. This perspective is also shown in a frequency count of multiple-choice, closed question which was provided to respondents (see Table 2 ).

Table 3 shows that for the companies in our interview sample a single ERP system allowed the HQ to focus on core roles and responsibilities, and make it less dependent on information from subsidiaries. We were further interested to find out whether the use of ERP in the organization had changed the formal structure of the HQ-subsidiary relationship. Thus, we asked our interview partners to provide some open response, reflect on critical incidents which substantiated their arguments and recount some histories. The following two statements are very pointed and illustrate the central argument:

- "There is more control across all of the functions..."

- "HQ is more directive. We are no longer hoodwinked by the subsidiaries in terms of them indicating that they know best, because we now can assess facts..."

Interestingly, subsidiaries in our interview sample, which traditionally have a strong ICT enabled governance structure, e.g. IT companies and phone companies, appear to be different. Managers from these company contexts considered ERP not to have changed any structures. They argued that ERP just improved efficiency and thus changes were witnessed purely on a reporting level.

In line with the question of changes of ERP to the formal structure in HQ-subsidiary relationships, we also asked how the use of ERP had changed the informal structure of HQ/subsidiary relations. In this specific context, we were particularly

Table 2

Influencing factors on choice between centralized or fragmented ERP solution.

\begin{tabular}{lcr}
\hline & Responses & Percent \\
\cline { 2 - 3 } & $N$ & 31.91 \\
\hline Greater visibility of operational decision making & 15 & 29.79 \\
Better control, access to information & 14 & 17.02 \\
Adaptability to local requirements & 8 & 10.64 \\
Problems with using multiple vendors & 5 & 10.64 \\
Chance to use appropriate interfaces & 5 & 100 \\
\end{tabular}

Note: $N$, count of responses on a set of multiple-response questions; percent, percentage of influencing factors in the multiple-response set of questions. 
Table 3

Effects of ERP systems.

\begin{tabular}{|c|c|c|c|c|c|}
\hline & 1 & 2 & 3 & 4 & 5 \\
\hline Single ERP system allows HQ to focus on core roles and responsibilities & 1 & 2 & 6 & 2 & 4 \\
\hline The deployment of an organization wide ERP system makes HQ less dependent on information from subsidiaries & 2 & 2 & 3 & 5 & 3 \\
\hline The ERP system affects interfirm negotiation such that the HQ can exercise more authority in dealing with subsidiaries & & 2 & 5 & 7 & 1 \\
\hline $\begin{array}{l}\text { The extent to which HQ needs to rely on local tacit knowledge, provided by subsidiaries, has decreased due to } \\
\text { ERP implementation }\end{array}$ & 3 & 1 & 5 & 5 & 1 \\
\hline
\end{tabular}

Note: 1 , strongly disagree; 5 , strongly agree; bold and highlighted numbers point at high level of multiple responses, representing significant levels of agreement.

concerned with, e.g. organizational layers, dotted lines in organizational structures and redesign of work content due to ICT/ ERP implementation. The most vocal responses are provided below and clearly demonstrate that due to ERP implementation the explicit dimension of knowledge exchange is much improved; impacting significantly on the way informal communication takes place.

- "Due to ERP, HQ is less dependent on informal communication..."

- "Possibilities for negotiations have reduced drastically"

- "The more data you have, the more control"

\section{Conclusions and implications}

\subsection{Back to the future - ICT induced return towards centralized structures}

Our empirical explorations demonstrate that ICT, specifically the implementation of ERP software contributes to a significant shift in coordination and control issues in MNE-subsidiary relationships. The paper applies a resourcedependency perspective to intra-MNE power [55,56], and examines the effect of the deployment of advanced ICT and particularly the implementation of enterprise resource planning (ERP). The specific focus is on the relationship between HQ and their international subsidiaries. From an organizational viewpoint, subsidiaries in the multinational do not have authority-based or 'structural' power with respect to key strategic decisions [6,16], but they benefit from 'resource-based power' in that they can exploit strategic knowledge advantages over their HQ. Subsidiaries benefit from capabilities to the extent that their proximity to the host markets is of value to the multinational as a whole. Business network analysis highlights the 'invisibility' to the upper echelons in the multinational of the external networks (often in the host country) through which valuable subsidiary knowledge and capabilities develop and points out that this 'invisibility' undermines the headquarters' ability to control the subsidiary [3,28,36,44,70,74].

In this paper we empirically explore the notion that the deployment of ERP undermines the resource base of subsidiary power and, in fact, restores greater central authority to the multinational enterprise HQs. Our findings provide support through studies of 12 multinational enterprises which have implemented ERP over the past years. The analysis of detailed semi-structured interviews indicates that from the perspective of subsidiary managers a key effect of ERP deployment is the greater visibility to HQ in terms of operational decision making and the more centralized control and management which leads to a reduction in subsidiary autonomy. HQ are increasingly perceived to show their prowess in terms of giving more directives, reduced flexibility in negotiations and using the reduced informational asymmetry between HQ and subsidiaries to favor their own interests.

Overall our empirical explorations demonstrate that the changes in the landscape of ICT, with particular reference to ERP systems, can be seen as a parallel development to the changes in the MNE structure. In the ICT context there has been a movement from the age of 'big computing' to 'personal computing' to 'networked computing' [1]. The introduction of ERP/ SAP is in one sense a movement back to 'big computing', i.e. a much more centralized approach towards ICT configurations and architecture. While the MNE has traditionally evolved from a unitary organization with replica subsidiaries, it developed into federative structures and is now increasingly moving back again towards centralized structures ('flagship' MNEs, see Ref. [58]).

\subsection{Implications for multinational enterprise futures}

In terms of implications for the future of the MNE and their subsidiaries, our study supports Birkinshaw's notion of subsidiaries as an 'endangered species' [10], as ICT changes can be linked to changes in corporate structures and a dilution of the power of subsidiaries over their corporate MNE partners [73]. With the power base of MNEs HQs increasing, they are forcing through drastic reductions in the scope of value chain activities for subsidiaries. Subsidiaries are increasingly 'aligned' and must agree 'to the book', which lays down in great detail how to organize their R\&D, plan production schedules and deliver their products to internal and external customers of the MNE [53]. While this may provide opportunities for some subsidiaries to become tight members of an 'in-crowd' [49,50] and more important allies in the network [15], the 
overarching picture for the subsidiaries will most probably be an oblique one, with substantially reduced voice in the corporate system.

Subsidiaries gain capabilities which are a function of their embeddedness in their local economies. These linkages are important to the rest of the organization and contribute to the long-term economic performance of the organization as well as the legitimacy in the host economic environment. Effectively, ICT has the potential to undermine the resource base of subsidiary power and may help to reinstate greater levels of MNE authority in the MNE-subsidiary relationship. This suggests that such capability development in the local economy of subsidiaries is at stake, and thus puts the 'advantage of multinationality' $[71,74]$ at risk.

The heightened tension between central authority and multinational legitimacy is particularly pertinent with established markets becoming saturated, and MNEs increasingly turn to emerging markets in the developing world. London and Hart [46] suggest that companies in pursuit of 'non-traditional' strategies in less-developed countries (LDCs) are most likely to succeed. Their strategies include the development of relationships with non-traditional partners, co-inventing custom solutions, and building local capacity. Success strategies relate to the development of a globally dispersed capability in 'social embeddedness', which implies that MNEs demonstrate leniency and acceptability to local responsiveness and subsidiary initiatives $[9,13]$. In fact it is probably the case that social embeddedness is a more demanding phenomenon than business embeddedness, which has been quite extensively studied (e.g. [29]). Business embeddedness is generally a process of sustained relationship with already existing businesses in the host environment (i.e. suppliers and/or customers) whereas social embeddedness is a more defused process that entails collaboration with non-traditional partners and the creation of local capabilities. It also relates to fostering a climate of social entrepreneurship, which is not solely aimed at the pursuit of economic interests [57], but to foster social progress [47,61]. To this end, social entrepreneurship will require a high degree of empathy with fundamental institutions of host countries and can enhance the legitimacy of MNEs' operations abroad. Cultivating the capability for social entrepreneurship is thus incompatible with an organizational structure in which the HQ is intolerant with respect to subsidiary creativity and autonomous - locally based, initiatives. This is an issue we would expect to feature significantly on the research agenda for MNE futures.

\section{References}

[1] S. Alsop, Is there life after ERP? For the valley, maybe not, Fortune 138 (3) (1998) 231-233.

[2] E Anderson, R.L. Oliver, Perspectives on behavior-based versus outcome-based salesforce control systems, Journal of Marketing 51 (4) (1987) 76-87.

[3] U. Andersson, M. Forsgren, Subsidiary embeddedness and control in the multinational corporation, International Business Review 5 (5) (1996) 487-508.

[4] U. Andersson, D.B. Holm, M. Johanson, Moving or doing? Knowledge flow, problem solving, and change in industrial networks, Journal of Business Research 60 (1) (2007) 32-40.

[5] U Andersson, C. Pahlberg, Subsidiary influence on strategic behaviour in MNCs: an empirical study, International Business Review 6 (3) (1997) 319-334.

[6] S.B. Bacharach, E.J. Lawler, Power and Politics in Organizations (The Jossey-Bass Social and Behavioral Science Series), Jossey-Bass, San Francisco, 1980.

[7] B. Barnes, The Nature of Power, Polity, Cambridge, 1988.

[8] J. Birkinshaw, How multinational subsidiary mandates are gained and lost, Journal of International Business Studies 27 (3) (1996) $467-495$.

[9] J. Birkinshaw, Entrepreneurship in multinational corporations: the characteristics of subsidiary initiatives, Strategic Management Journal 18 (3) (1997)207229.

[10] J. Birkinshaw, Strategy and management in MNE subsidiaries, in: A.M. Rugman, T.L. Brewer (Eds.), The Oxford Handbook of International Business, Oxford University Press, Oxford, 2001, pp. 380-401.

[11] J. Birkinshaw, N. Hood, Multinational subsidiary evolution: capability and charter change in foreign-owned subsidiary companies, Academy of Management Review 23 (4) (1998) 773-795.

[12] J. Birkinshaw, T. Omar, A. David, Global account management in multinational corporations: theory and evidence, Journal of International Business Studies 32 (2) (2001) 231-248.

[13] J. Birkinshaw, J. Ridderstrale, Fighting the corporate immune system: a process study of subsidiary initiatives in multinational corporations, International Business Review 8 (2) (1999) 149-180.

[14] J.M. Birkinshaw, A.J. Morrison, Configurations of strategy and structure in subsidiaries of multinational corporations, Journal of International Business Studies 26 (4) (1995) 729-754.

[15] C. Bouquet, J. Birkinshaw, Managing power in the multinational corporation: how low-power actors gain influence, Journal of Management 34 (3) (2008) 477-508.

[16] M.Z. Brooke, Centralization and Autonomy: A Study in Organization Behaviour (Praeger Special Studies), Holt Rinehart and Winston, London, 1984.

[17] P.J. Buckley, P.N. Ghauri, Globalisation, economic geography and the strategy of multinational enterprises, Journal of International Business Studies 35 (2) (2004) 81-98.

[18] K.S Celly, G.L. Frazier, Outcome-based and behavior-based coordination efforts in channel relationships, Journal of Marketing Research 33 (2) (1996) 200210.

[19] K.S. Cook, R.M. Emerson, Exchange networks and the analysis of complex organizations, Sociology of Organizations 3 (1984) 1-10.

[20] J. Corbin, A. Strauss, Grounded theory research: procedures, canons, and evaluative criteria, Qualitative Sociology 13 (1) (1990) 3-21.

[21] J Crotty, The neoliberal paradox: the impact of destructive product market competition and 'modern' financial markets on nonfinancial corporation performance in the neoliberal era, in: G.A. Epstein (Ed.), Financialization and the World Economy, Edward Elgar Pub., Cheltenham, UK, 2005, pp. 77-110.

[22] D.A. Dillman, Mail and Internet Surveys: The Tailored Design Method, John Wiley \& Sons, New York, NY, 2000.

[23] Y. Doz, C.K. Prahalad, Patterns of strategic control within multinational corporations, Journal of International Business Studies 15 (2) (1984) 55-72.

[24] M. Easterby-Smith, R. Thorpe, A. Lowe, 2nd ed., Management Research: An Introduction (Sage Series in Management Research), Sage Publications, London, 2002.

[25] R.M. Emerson, Social exchange theory, Annual Review of Sociology 2 (1976) 335-362.

[26] A. Femer, P. Almond, I. Clark, T. Coiling, T. Edwards, L. Holden, M. Muller-Camen, The dynamics of central control and subsidiary autonomy in the management of human resources: case-study evidence from US MNCs in the UK, Organization Studies 25 (3) (2004) $363-391$.

[27] A. Ferner, The underpinnings of 'bureaucratic' control systems: HRM in European multinationals, Journal of Management Studies 37 (4) (2000) 521-540.

[28] M. Forsgren, U. Holm, J. Johanson, Division headquarters go abroad - a step in the internationalization of the multinational corporation, Journal of Management Studies 32 (4) (1995) 475-491.

[29] M. Forsgren, U. Holm, J. Johanson, Managing the Embedded Multinational: A Business Network View, Edward Elgar, Cheltenham, 2005.

[30] T.S. Frost, J.M. Birkinshaw, P.C. Ensign, Centers of excellence in multinational corporations, Strategic Management Journal 23 (11) (2002) $997-1018$. 
[31] S. Ghoshal, C.A. Bartlett, The multinational corporation as an interorganizational network, Academy of Management Review 15 (4) (1990) 603-625.

[32] D.D. Gremler, The critical incident technique in service research, Journal of Service Research 7 (1) (2004) 65-89.

[33] V. Grover, K.A. Saeed, The impact of product, market, and relationship characteristics on interorganizational system integration in manufacturer-supplier dyads, Journal of Management Information Systems 23 (4) (2007) 185-216.

[34] J.B Heide, K.H. Wathne, A.I. Rokkan, Interfirm monitoring, social contracts, and relationship outcomes, Journal of Marketing Research 44 (3) (2007) $425-433$.

[35] K. Hewett, M.S. Roth, K. Roth, Conditions influencing headquarters and foreign subsidiary roles in marketing activities and their effects on performance, Journal of International Business Studies 34 (6) (2003) 567-585.

[36] U. Holm, J. Johanson, Headquarters' knowledge of subsidiary network contexts in the multinational corporation, International Studies of Management \& Organization $25(1 / 2)(1995) 97-119$.

[37] U. Holm, J. Johanson, P. Thilenius, Headquarters' knowledge of subsidiary network contexts in the multinational corporation, International Studies of Management \& Organization $25(1,2)(1995)$ 97-120.

[38] J.C. Jarillo, J.I. Martíanez, Different roles for subsidiaries: the case of multinational corporations in Spain, Strategic Management Journal 11 (7) (1990) 501512.

[39] R.-J.B. Jean, The ambiguous relationship of ICT and organizational performance: a literature review, Critical Perspectives on International Business 3 (4) (2007) 306-321.

[40] R.-J.B. Jean, R.R. Sinkovics, S.T. Cavusgil, Enhancing international customer-supplier relationships through IT resources: A study of Taiwanese electronics suppliers, Journal of International Business Studies 41 (2010) 1218-1239.

[41] R.-J.B. Jean, R.R. Sinkovics, D. Kim, Drivers and performance outcomes of relationship learning for suppliers in cross-border customer-supplier relationships: The role of communication culture, Journal of International Marketing 18 (1) (2010) 63-85.

[42] R.-J.B. Jean, R.R. Sinkovics, D. Kim, Information technology and organizational performance within international business to business relationships: a review and an integrated conceptual framework, International Marketing Review 25 (5) (2008) 563-583.

[43] D. Krackhardt, Power in and around organizations, Administrative Science Quarterly 30 (4) (1985) 597-600.

[44] D. Krackhardt, Assessing the political landscape: structure, cognition, and power in organizations, Administrative Science Quarterly 35 (2) (1990) 342-369.

[45] D.A Levinthal, J.G. March, The myopia of learning, Strategic Management Journal 14 (S2) (1993) 95-112.

[46] T. London, S.L. Hart, Reinventing strategies for emerging markets: beyond the translational model, Journal of International Business Studies 35 (5) (2004) 350-370.

[47] J. Mair, I. Martí, Social entrepreneurship research: a source of explanation, prediction, and delight, Journal of World Business 41 (1) (2006) 36-44.

[48] J.W Medcof, Resource-based strategy and managerial power in networks of internationally dispersed technology units, Strategic Management Journal 22 (11) (2001) 999-1012.

[49] L.F. Monteiro, N. Arvidsson, J. Birkinshaw, Knowledge flows within multinational corporations: explaining subsidiary isolation and its performance implications, Organization Science 19 (1) (2008) 90-107.

[50] L.F. Monteiro, J. Birkinshaw, N. Arvidsson, Being in the "out" crowd, MIT Sloan Management Review 49 (2) (2008) 13-14.

[51] G. Morgan, The multinational firm: organizing across institutional and national divides, in: G. Morgan, P.H. Kristensen, R. Whitley (Eds.), The Multinational Firm: Organizing Across Institutional and National Divides, Oxford University Press, Oxford, 2003.

[52] R. Mudambi, P. Navarra, Is knowledge power? Knowledge flows, subsidiary power and rent-seeking within MNCs, Journal of International Business Studies 35 (5) (2004) 385-406.

[53] P Nolan, D. Sutherland, J. Zhang, The challenge of the global business revolution, Contributions to Political Economy 21 (1) (2002) 91-110.

[54] M. O'Sullivan, Contests for Corporate Control: Corporate Governance and Economic Performance in the United States and Germany, Oxford University Press, Oxford, 2000

[55] J. Pfeffer, Power in Organizations, Pitman, Marshfield, MA, 1981.

[56] J. Pfeffer, G.R. Salancik, The External Control of Organizations: A Resource Dependence Perspective, Harper \& Row, New York, 1978.

[57] C.K. Prahalad, The Fortune at the Bottom of the Pyramid: Eradicating Poverty Through Profits, Wharton School Publishing, Upper Saddle River, NJ, 2004.

[58] A.M. Rugman, J.R. D'Cruz, Multinationals as Flagship Firms: Regional Business Networks, Oxford University Press, Oxford, 2003.

[59] A.M. Rugman, A. Verbeke, Subsidiary-specific advantages in multinational enterprises, Strategic Management Journal 22 (3) (2001) 237-250.

[60] S. Ryu, S. Kabadayi, C. Chung, The relationship between unilateral and bilateral control mechanisms: the contextual effect of long-term orientation, Journal of Business Research 60 (7) (2007) 681-689.

[61] C. Seelos, J. Mair, Social entrepreneurship: creating new business models to serve the poor, Business Horizons 48 (3) (2005) $241-246$.

[62] L.H. Shi, S. Zou, J.C. White, R.C. McNally, S.T. Cavusgil, Executive insights: global account management capability: insights from leading suppliers, Journal of International Marketing 13 (2) (2005) 93-113.

[63] L.O. Silva, Theoretical approaches for researching power and information systems: the benefit of a Machiavellian view, in: D. Howcroft, E.M. Trauth (Eds.), Handbook of Critical Information Systems Research: Theory and Application, Edward Elgar, Cheltenham, UK, 2005, pp. 47-69.

[64] R.R. Sinkovics, E. Penz, P.N. Ghauri, Analysing textual data in international marketing research, Qualitative Market Research: An International Journal 8 (1) (2005) 9-38.

[65] R.R. Sinkovics, E. Penz, P.N. Ghauri, Enhancing the trustworthiness of qualitative research in international business, Management International Review 48 (6) (2008) 689-714.

[66] Ö. Sölvell, I. Zander, Organization of the dynamic multinational enterprise: the home-based and the hierarchical MNE, International Studies of Management \& Organization $25(1,2)(1995) 17-38$.

[67] R. Strange, J. Newton, Stephen hymer and the externalization of production, International Business Review 15 (2) (2006) 180-193.

[68] J.H. Taggart, Strategy shifts in MNC subsidiaries, Strategic Management Journal 19 (7) (1998) 663-681.

[69] M. Weber, The Theory of Social and Economic Organization, Oxford University Press, New York, 1947.

[70] W.-P. Wu, Dimensions of social capital and firm competitiveness improvement: the mediating role of information sharing, Journal of Management Studies 45 (1) (2008) 122-146.

[71] M. Yamin, Subsidiary entrepreneurship and the advantage of multinationality, in: V. Havila, M. Forsgren, H. Hakansson (Eds.), Critical Perspectives on Internationalisation, Pergamon Press, Oxford, 2002, pp. 133-150.

[72] M. Yamin, Subsidiary business networks and opportunity development in multinational enterprises: a comparison of the influence of internal and external business networks, in: P.N. Ghauri, A. Hadjikhani (Eds.), Business Opportunity Development in Business Networks, Palgrave Macmillan, London, 2005, pp. $91-109$.

[73] M. Yamin, M. Forsgren, Hymer's analysis of the multinational organization: power retention and the demise of the federative MNE, International Business Review 15 (2) (2006) 166-179.

[74] M. Yamin, R.R. Sinkovics, ICT and MNE reorganisation: the paradox of control, Critical Perspectives on International Business 3 (4) (2007) 322-336. 